次のよらにまとめられる.

（1）ガラス量が多い場合はそのガラスの屈伏点以上 の温度で加圧焼結すればほぼ完全にち密化した混合焼結 体が得られた。

（2）微粒の銅粉を混合する方が比較的少量の混合で 混合焼結体中の銅相のつながりができるから，熱伝導率 の向上に効果的である. 粗粒の銅粉を混合した場合は銅 が熱伝導率の悪いガラス中に分散するため, 熱伝導率の 向上は悪い。

（3）微粉の銅を用いた混合焼結体では，銅粉の混合 量が少量の時は, 混合熱伝導則の一つである対数則に従 ってその熱伝導率は変化し, ある程度以上の混合量とな ると銅相が連続化するため, 対数則よりはずれて急激に 大きくなる．しかし熱伝導の良い銅が連続相であるモデ ルから予想されるほどには大きくならない。一方粗粒の 銅粉を用いた場合は, 熱伝導の良い銅が分散しているモ
デルによる熱伝導率とよい一致を示した。

\section{文献}

1) 寺井良平, セラミックス, 11, 226 (1976).

2) 角田直己, ibid., 12, 913 (1977).

3) G.H. Jenks and C.D. Bopp, Energy Storage in HighLevel Radioactive Wastes and Simulation and Measurement of Stored Energy with Synthetic Wastes, ORNL-TM-3781 (1973).

4) J. van Geel, H. Eschrich, H. Heimerl and P. Grziwa, Int. Symp. on the Management of Radioactive Wastes from the Nuclear Fuel Cycle, Vienna, IAEA-SM-207/ 83 (1976).

5）木下 実, 若林 博, 大工試季報, 24, 208 (1973).

6) W.D. Kingery, H.K. Bowen and D.R. Uhlmann, "Introduction to Ceramics", 2nd Ed., John Wiley \& Sons Inc. (1976) p. 634.

7) A. Eucken, Forsch. Gebiete Ingenieurw., Bd. 3; Forschungsheft, 353 (1932).

8）岩佐美喜男，木下 実，寺井良平，第 17 回窯業基礎討論 会講演要旨集, 89 (1979).

\title{
Thermal Decomposition Reaction of Sialon
}

\author{
Mamoru MITOMO, Nobuyuki KURAMOTO* \\ and Yoshiyuki YAJIMA \\ ( National Institute for Researches in Inorganic Materials, Niihari-gun 305 ) \\ * Tokuyama Soda Co., Ltd., Tokuyama-shi 745
}

Thermal decomposition of sialon was performed by heating two-phase sialon consisting of both $\beta$-sialon with $z=2.3$ and $\mathrm{X}$-sialon and single-phase $\beta$-sialon $\left(z=2, \mathrm{Si}_{4} \mathrm{Al}_{2} \mathrm{O}_{2} \mathrm{~N}_{6}\right)$ at $1800^{\circ} \mathrm{C}$ under $1 \mathrm{~atm} \mathrm{~N}_{2}$. Changes in composition and phase were studied by means of X-ray diffraction and chemical analysis.

The reactions are inferred to be,

$$
\beta_{1} \text {-sialon }(\mathrm{s})+\mathrm{X} \text {-sialon }(\mathrm{l})=\beta_{2} \text {-sialon }(\mathrm{s})+6 \mathrm{SiO}(\mathrm{g})+2 \mathrm{~N}_{2}(\mathrm{~g})
$$

for the two-phase sialon and,

$$
\beta \text {-sialon }(\mathrm{s})=15 \mathrm{R} \text {-sialon }(\mathrm{s})+4 \mathrm{SiO}(\mathrm{g})+2 \mathrm{~N}_{2}(\mathrm{~g})+\mathrm{Si}(\mathrm{l})
$$

for the single-phase sialon.

The region of $\mathrm{SiO}$ pressure for the stable single-phase $\beta$-sialon under total pressure of $1 \mathrm{~atm}$ was calculated to be from $6.0 \times 10^{-1}$ to $3.9 \times 10^{-1} \mathrm{~atm}$ at $1800^{\circ} \mathrm{C}$ assuming intermediate stages.

The methods to fabricate $\beta$-sialon by reaction sintering, published up to date, were discussed in terms of $\mathrm{SiO}$ pressure around the compact. The method to sinter the compact in loose powder of $\mathrm{Si}_{3} \mathrm{~N}_{4}$ and $\mathrm{SiO}_{2}$, which was developed by present authors, was the most successful because of the formation of sufficient pressure of $\mathrm{SiO}\left(4.8 \times 10^{-1} \mathrm{~atm}\right.$ at $\left.1800^{\circ} \mathrm{C}\right)$ to prevent the thermal decomposition of $\beta$-sialon described above.

The result of present study enables the fabrication of high density $\beta$-sialon with small amount of intergranular phase by the reaction sintering.

[Received April 2, 1979] 


\title{
サイアロンの熱分解反応
}

\author{
三友 護・倉元信行*. 矢島祥行 \\ $\left(\begin{array}{c}\text { 無機材質研究所 } \\ * \text { 徳山曹達 }(\text { 株 })\end{array}\right)$
}

\begin{abstract}
$\beta$-サイアロン $(z=2.3)$ とX-サイアロンからなる 2 相サイアロン及び単相の $\beta$-サイアロン $(z=$ 2, $\left.\mathrm{Si}_{4} \mathrm{Al}_{2} \mathrm{O}_{2} \mathrm{~N}_{6}\right)$ の粉末を 1 気圧の窒素中で加熱することにより熱分解を行った. 組成及び相の変 化をX線回折及び化学分析で調べた.

2 相サイアロンの熱分解反応は，$$
\beta_{1} \text {-サイアロン }(\mathrm{s})+\mathrm{X} \text {-サイアロン }(\mathrm{l})=\beta_{2} \text {-サイアロン }(\mathrm{s})+6 \mathrm{SiO}(\mathrm{g})+2 \mathrm{~N}_{2}(\mathrm{~g})
$$

単相サイアロンは,$$
\text { ß-サイアロン }(\mathrm{s})=15 \mathrm{R} \text {-サイアロン }(\mathrm{s})+4 \mathrm{SiO}(\mathrm{g})+2 \mathrm{~N}_{2}(\mathrm{~g})+\mathrm{Si}(\mathrm{l})
$$

と推定された.

中間状態を仮定することにより $\beta$-サイアロンの安定な $\mathrm{SiO}$ 分圧は $1800^{\circ} \mathrm{C}$ で, $6.0 \times 10^{-1}$ と $3.9 \times 10^{-1}$ 気圧の間であると算出できた.

今までに報告されている $\beta$-サイアロンの反応燒結法を成形体上の $\mathrm{SiO}$ 分圧といら観点から検討 した. 著者らが開発した $\mathrm{Si}_{3} \mathrm{~N}_{4}$ と $\mathrm{SiO}_{2}$ の混合粉末でお扔う方法が最も有効であった. それは成 形体上に $1800^{\circ} \mathrm{C}$ で $4.8 \times 10^{-1}$ 気圧の $\mathrm{SiO}$ が存在し， $\beta$-サイアロンの熱分解を抑えるためである.

本研究の結果, 粒界相が少量しか存在しない高密度 $\beta$-サイアロンの反応焼結が可能となった.
\end{abstract}

(1979 年 4 月 2 日受付)

\author{
Key-words : Sialon, Thermal decomposition, $\mathrm{SiO}$ pressure, Reaction sintering, Weight \\ loss
}

\section{Introduction}

A solid solution of $\mathrm{Si}_{3} \mathrm{~N}_{4}$ with $\mathrm{AlN} \cdot \mathrm{Al}_{2} \mathrm{O}_{3}$, which has $\beta-\mathrm{Si}_{3} \mathrm{~N}_{4}$ structure, is called as $\beta$ sialon in present work to avoid a confusion with other sialons. Number of works have been done on fabrications and measurements of mechanical properties of $\beta$-sialon ${ }^{1) ~ 3)}$. The materials were mostly obtained by hot pressings.

Attempts have been made to fabricate $\beta$ sialon by the reaction sinterings or the pressureless sintering to apply it as high temperature engineering materials ${ }^{4) \sim 6)}$. The method would enable to supply sintered $\beta$-sialons with high density and complex shapes. But a lack in information on thermochemical properties of $\beta$-sialon prevented us to fabricate it under stable conditions.

Goursat $^{7)}$ recently reported that sialons decomposed thermally and formed gaseous products containing $\mathrm{Si}, \mathrm{O}$ and $\mathrm{N}$. The formation of $\mathrm{SiO}$ by the thermal decomposition of $\beta$-sialon was already assumed ${ }^{8,9)}$. The equilibrium partial pressure of $\mathrm{SiO}$ was not esti- mated, because thermochemical data on sialons were not available yet.

The sintering of $\mathrm{Si}_{3} \mathrm{~N}_{4}$ with additives were successfully carried out under high nitrogen pressures $^{10)}$. The method made possible to decrease the amount of weight loss due to thermal decomposition by depressing an equilibrium $\mathrm{Si}$ vapor pressure at high temperatures $^{10), 11)}$. It is due to the fact that the stability of $\mathrm{Si}_{3} \mathrm{~N}_{4}$ at high temperature is directly related to $\mathrm{N}_{2}$ pressure on $\mathrm{Si}_{3} \mathrm{~N}_{4}$ as shown by thermal decomposition reaction,

$$
\left.\mathrm{Si}_{3} \mathrm{~N}_{4}(\mathrm{~s})=3 \mathrm{Si} \text { (s or } 1\right)+2 \mathrm{~N}_{2}(\mathrm{~g}) \quad(1)
$$

No attempt has been made to sinter $\beta$-sialon under sufficient pressures of gaseous species which are formed by the thermal decomposition of $\beta$-sialon.

The present work intends to estimate equilibrium pressures of $\mathrm{SiO}$ on $\beta$-sialon under a total pressure of $1 \mathrm{~atm}$ by approximate calculations. The necessity to sinter $\beta$-sialon under sufficient $\mathrm{SiO}$ pressure will be discussed with respect to the weight loss during sintering and resulting changes in composition. 


\subsection{Materials}

\section{Experimental}

Two kinds of sialon powder were obtained by heating the powder mixtures of $\mathrm{Si}, \mathrm{AlN}$ and/or $\mathrm{Al}_{2} \mathrm{O}_{3}$ at $1350^{\circ} \mathrm{C}$ for $20 \mathrm{~h}$ and $1450^{\circ} \mathrm{C}$ for $5 \mathrm{~h}$ in $\mathrm{N}_{2}$ containing $20 \mathrm{vol} \% \mathrm{H}_{2}$. These sialon powders were (1) "two-phase sialon" containing both $\beta$-sialon with $z=2.3$ in general formula $\mathrm{Si}_{6-z} \mathrm{Al}_{z} \mathrm{O}_{z} \mathrm{~N}_{8-z}$ and X-sialon, the composition of which is represented by " $\mathrm{A}$ " in Fig. 1, and (2) "single-phase sialon" with $z=$ 2 ("B" in Fig. 1).

The contents of $\mathrm{Si}, \mathrm{Al}$ and $\mathrm{N}$ were determined by chemical analyses and shown as "original" in Table 1.

\subsection{Thermal decomposition}

The powder specimen was heated at $1800^{\circ} \mathrm{C}$ for $1 \mathrm{~h}$ in $\mathrm{N}_{2}$ to investigate the thermal decomposition process of sialons. The composition and crystalline phases in residual solid were determined by X-ray diffraction and chemical analysis.

The thermodynamic calculation for $\mathrm{SiO}$ pressure on sialons was performed by assuming intermediate stages.

\section{Results and discussions}

\subsection{Thermal decomposition of sialons}

The chemical analysis of thermally decomposed sialon powders revealed the decrease in $\mathrm{Si}$ and $\mathrm{O}$ content as shown in Table 1. The shifts in composition from the originals were shown in Fig. 1 as arrows in the $\mathrm{Si}_{3} \mathrm{~N}_{4}-\mathrm{SiO}_{2}-$ $\mathrm{Al}_{2} \mathrm{O}_{3}-\mathrm{AlN}$ phase diagram ${ }^{12)}$. The figure clearly showed that the compositions of sialons were shifted toward $\mathrm{AlN}$ or $\mathrm{AlN}-\mathrm{Si}_{3} \mathrm{~N}_{4}$ line from the original positions by the thermal decomposition.

Phase analyses of the original and the thermally decomposed sialons showed the decrease of X-sialon in the two-phase material and the

Table 1. The results of chemical analyses of original and thermally decomposed sialons.

\begin{tabular}{|l|c|c|c|c|c|}
\hline \multirow{2}{*}{ Sample } & \multicolumn{4}{|c|}{ Analytical value (wt \%) } \\
\cline { 2 - 6 } & Si & A1 & N & $0^{*}$ \\
\hline \multirow{2}{*}{$\begin{array}{l}\text { Two-phase } \\
\text { sialon }\end{array}$} & origina1 & 35.9 & 21.2 & 23.7 & 19.2 \\
\hline \multirow{2}{*}{$\begin{array}{l}\text { Single-phase } \\
\text { sialon }\end{array}$} & decomposed & 34.0 & 23.3 & 24.8 & 17.9 \\
\cline { 2 - 6 } & origina1 & 41.2 & 18.0 & 28.5 & 12.3 \\
\hline
\end{tabular}

* by difference.

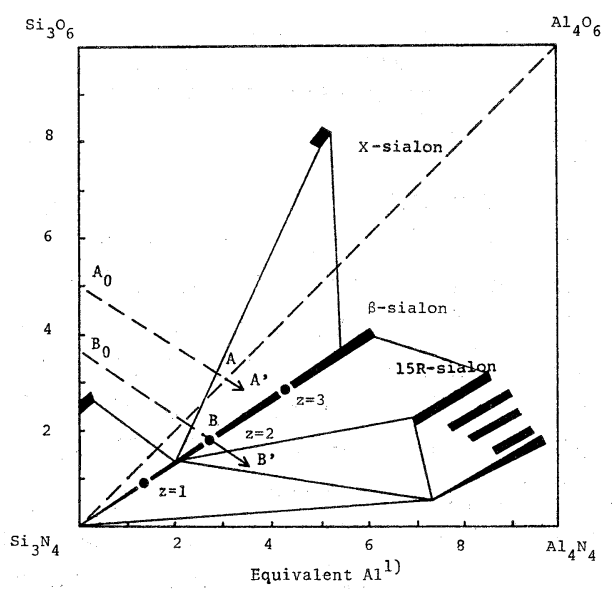

Fig. 1. The change in composition by thermal decomposition of two-phase sialon $(\mathrm{A} \rightarrow$ $\left.A^{\prime}\right)$ and single-phase sialon $\left(B \rightarrow B^{\prime}\right)$.

formation of $15 \mathrm{R}$-sialon in the single-phase sialon by the thermal decomposion. The increased $z$ value of $\beta$-sialon compared to the original after the decomposition of the twophase sialon and the formation of $15 \mathrm{R}$-sialon from the single-phase sialon with $z=2$ was consistent with phase diagram (Fig. 1).

The reverse extraporation of arrows to a $\mathrm{Si}_{3} \mathrm{~N}_{4}-\mathrm{SiO}_{2}$ axis in Fig. 1 showed that materials evaporated during the heating at $1800^{\circ} \mathrm{C}$ correspond to the composition $\mathrm{A}_{0}\left(\mathrm{Si}_{3} \mathrm{~N}_{4}+\right.$ $\left.3 \mathrm{SiO}_{2}\right)$ and $\mathrm{B}_{0}\left(\mathrm{Si}_{3} \mathrm{~N}_{4}+2 \mathrm{SiO}_{2}\right)$ in the twophase and the single-phase sialon respectively.

\subsection{Thermal decomposition of two- phase sialon}

The evaporation of materials from the twophase sialon might be due to the formation of gaseous species ${ }^{8}$,

$$
\mathrm{Si}_{3} \mathrm{~N}_{4}(\mathrm{~s})+3 \mathrm{SiO}_{2}(\mathrm{l})=6 \mathrm{SiO}(\mathrm{g})+2 \mathrm{~N}_{2}(\mathrm{~g})
$$

The reaction actually observed might be,

$$
\begin{aligned}
& \beta_{1} \text { - } \operatorname{sialon}(\mathrm{s})+\mathrm{X} \text {-sialon }(\mathrm{l}) \\
& \quad=\beta_{2}-\operatorname{sialon}(\mathrm{s})+6 \mathrm{SiO}(\mathrm{g})+2 \mathrm{~N}_{2}(\mathrm{~g})
\end{aligned}
$$

The $z$ value of $\beta_{1}$-sialon was 2.3 and that of $\beta_{2}$-sialon was larger than 2.3.

The reaction can be divided into two reactions assuming an intermediate state as follows,

$$
\begin{aligned}
& \beta_{1} \text {-sialon }+\mathrm{X} \text {-sialon } \\
& \quad=\beta_{2} \text {-sialon }+\left(\mathrm{Si}_{3} \mathrm{~N}_{4}+3 \mathrm{SiO}_{2}\right) \\
& \beta_{2} \text {-sialon }+\left(\mathrm{Si}_{3} \mathrm{~N}_{4}+3 \mathrm{SiO}_{2}\right) \\
& \quad=\beta_{2} \text {-sialon }+6 \mathrm{SiO}+2 \mathrm{~N}_{2}
\end{aligned}
$$

Partial pressure of $\mathrm{SiO}$ in reaction. (3) is calculated by, 


$$
\begin{aligned}
\ln k_{\mathrm{p}} & =\ln (p \mathrm{SiO})^{6}\left(p \mathrm{~N}_{2}\right)^{2} \\
& =-\frac{\Delta G_{3}}{R T}=-\frac{\left(\Delta G_{4}+\Delta G_{5}\right)}{R T}
\end{aligned}
$$

and,

$$
p \mathrm{SiO}+p_{\mathrm{N}_{2}}=1
$$

where $\Delta G_{3}, \Delta G_{4}$ and $\Delta G_{5}$ are the free energy change for the reaction (3), (4) and (5), respectively. The value of $\Delta G_{5}$ is the same as $\Delta G_{2}$ and calculated as $17.1 \mathrm{kcal} / \mathrm{mol}$ at $1800^{\circ} \mathrm{C}$ using JANAF thermochemical data ${ }^{13}$. Phase studies on the system $\mathrm{Si}_{3} \mathrm{~N}_{4}-\mathrm{SiO}_{2}-\mathrm{Al}_{2} \mathrm{O}_{3}-$ $\mathrm{AlN}^{\left.1,{ }^{1}\right)}$ suggest that the free energy change for solid state reaction (4), $\Delta G_{4}$, is $>0$. But the value itself might be small compared to $\Delta G_{5}$, because the free energy changes in solid state reactions are generally very small. For example, free energy changes for formation of silicates from constituent oxides are,

$\Delta G=-0.29 \mathrm{kcal} / \mathrm{mol}$ at $1800 \mathrm{~K}$ for andalusite

$$
\mathrm{Al}_{2} \mathrm{O}_{3}+\mathrm{SiO}_{2}=\mathrm{Al}_{2} \mathrm{SiO}_{5} \text {, }
$$

$\Delta G=-4.75 \mathrm{kcal} / \mathrm{mol}$ at $2000 \mathrm{~K}$ for mullite,

$$
3 \mathrm{Al}_{2} \mathrm{O}_{3}+2 \mathrm{SiO}_{2}=3 \mathrm{Al}_{2} \mathrm{O}_{3} \cdot 2 \mathrm{SiO}_{2} \text {. }
$$

(The calculations were made using JANAF data $^{13)}$ and standard free energies for silicates ${ }^{14)}$ ). This suggests that $\Delta G_{4}$ might be neglected for approximate calculation of the $\mathrm{SiO}$ pressure by Equations (6) and (7). The pressure of $\mathrm{SiO}$ vapor, thus obtained, is 6.0 $\times 10^{-1} \mathrm{~atm}$ at $1800^{\circ} \mathrm{C}$.

\section{3 Thermal decomposition of single- phase sialon}

The thermal decomposition of single-phase $\beta$-sialon $(z=2)$ is considered to correspond to a reaction,

$$
\begin{aligned}
& \mathrm{Si}_{3} \mathrm{~N}_{4}(\mathrm{~s})+2 \mathrm{SiO}_{2}(\mathrm{l}) \\
& \quad=4 \mathrm{SiO}(\mathrm{g})+2 \mathrm{~N}_{2}(\mathrm{~g})+\mathrm{Si}(\mathrm{l})
\end{aligned}
$$

The thermal decomposition of $\beta$-sialon was observed to form $15 \mathrm{R}$-sialon and $\mathrm{Si}$,

$$
\begin{aligned}
\beta \text {-sialon }(\mathrm{s})= & 15 \mathrm{R} \text {-sialon }(\mathrm{s})+4 \mathrm{SiO}(\mathrm{g}) \\
& +2 \mathrm{~N}_{2}(\mathrm{~g})+\mathrm{Si}(\mathrm{l})
\end{aligned}
$$

The calculation of $\mathrm{SiO}$ pressure was made by the same procedure as for the two-phase sialon by assuming the intermediate stage, 15 R-sialon $+\left(\mathrm{Si}_{3} \mathrm{~N}_{4}+2 \mathrm{SiO}_{2}\right)$.

The calculated value of $\mathrm{SiO}$ pressure was 3.9 $\times 10^{-1} \mathrm{~atm}$ at $1800^{\circ} \mathrm{C}$.

The calculated results suggest that the single-phase $\beta$-sialon is more stable than the two-phase sialon when the vapor pressure of $\mathrm{SiO}$ on sialon powder is lower than $6.0 \times 10^{-1}$ atm at $1800^{\circ} \mathrm{C}$. And it does not decomposed to $15 \mathrm{R}$-sialon when the $\mathrm{SiO}$ pressure is higher

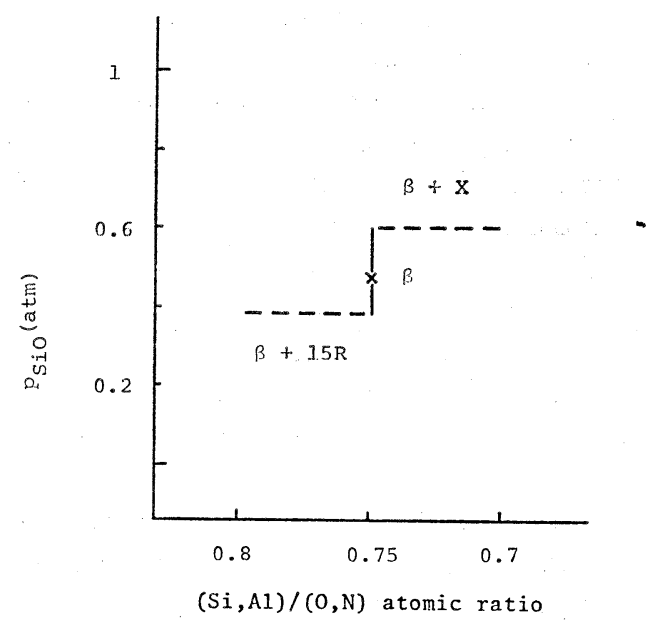

Fig. 2. The $\mathrm{SiO}$ pressure for single-phase $\beta$-sialon with $z \simeq 2$ at $1800^{\circ} \mathrm{C}$.

than $3.9 \times 10^{-1} \mathrm{~atm}$. The $\mathrm{SiO}$ vapor pressure region for the single-phase $\beta$-sialon with $z=2$ was estimated to be from $6.0 \times 10^{-1}$ to $3.9 \times$ $10^{-1} \mathrm{~atm}$ at $1800^{\circ} \mathrm{C}$ neglecting the difference in free energies of two $\beta$-sialons with little difference in $z$ values. The pressure of $\mathrm{SiO}$ for the stable $\beta$-sialon is shown in Fig. 2 as the function of $(\mathrm{Si}, \mathrm{Al}) /(\mathrm{O}, \mathrm{N})$.

\subsection{Reaction sintering of $\beta$-sialon}

An important problem on the reaction sintering of $\beta$-sialon by heating powder mixture of $\mathrm{Si}_{3} \mathrm{~N}_{4}-\mathrm{Al}_{2} \mathrm{O}_{3}-\mathrm{AlN}$ or $\mathrm{Si}_{3} \mathrm{~N}_{4}-\mathrm{SiO}_{2}-\mathrm{AlN}$ is how to prevent the weight loss due to the thermal decomposition during sintering. When the weight loss occurs, the composition deviates from $\beta$-sialon toward $\mathrm{AlN}-\mathrm{Si}_{3} \mathrm{~N}_{4}$ axis as already shown, thus results in incomplete shrinkage due to lack in sinterability ${ }^{15}$. To get a high density material, the composition must be rich in oxide over $\beta$-sialon, and this results in the formation of sintered material with large amount of intergranular X-sialon or glassy phase which degrades high temperature properties very much. The conclusion deduced from the present study is that the compact must be sintered under the sufficient $\mathrm{SiO}$ vapor pressure in order to obtain high density $\beta$-sialon with smaller amount of intergranular phase.

The reaction sintering of $\beta$-sialon was reported to be successfully performed by heating the compact packed with $\mathrm{Si}_{3} \mathrm{~N}_{4}$ powder ${ }^{6)}$ or powder mixture with same composition as the specimen compact ${ }^{5}$. But the compact composed of $\mathrm{Si}_{3} \mathrm{~N}_{4}, \mathrm{Al}_{2} \mathrm{O}_{3}$ and $\mathrm{AlN}$, which 
Table 2. The effect of kind of packing powder on the weight loss during sintering of $\beta$-sialon and the density of material.

\begin{tabular}{|c|c|c|}
\hline $\begin{array}{c}\text { Packing powder } \\
(\text { wt } \%)\end{array}$ & $\begin{array}{c}\text { weight loss } \\
(\text { wt } 8)\end{array}$ & $\begin{array}{c}\text { density of sintered } \\
\text { sialon }\left(\mathrm{g} / \mathrm{cm}^{3}\right)\end{array}$ \\
\hline $\mathrm{Si}_{3} \mathrm{~N}_{4}$ & 14.2 & 1.72 \\
\hline $\begin{array}{c}\mathrm{Si}_{3} \mathrm{~N}_{4}+\mathrm{Al}_{2} \mathrm{O}_{3}+\mathrm{AlN}^{*} \\
(66){ }_{(24)}(10)\end{array}$ & 7.3 & 2.11 \\
\hline $\begin{array}{r}\mathrm{Si}_{3} \mathrm{~N}_{4}+\mathrm{SiO}_{2} \\
(70)\end{array}$ & 0.4 & 2.96 \\
\hline
\end{tabular}

* corresponds to siajon with $z=2$.

were mixed to form sialon with $z=2$, showed appreciable weight loss after heating in $\mathrm{Si}_{3} \mathrm{~N}_{4}$ or powder mixture with the same composition at $1800^{\circ} \mathrm{C}$ for $1 \mathrm{~h}$ as shown in Table 2. The packing of the compact with the equi-molar mixture of $\mathrm{Si}_{3} \mathrm{~N}_{4}$ and $\mathrm{SiO}_{2}$, on the other hand, could prevent weight loss and form high density $\beta$-sialon.

The difficulty to prevent the thermal decomposition of sialon by packing the compact with $\mathrm{Si}_{3} \mathrm{~N}_{4}$ only could be well understood by the absence of $\mathrm{SiO}$ around the compact.

The formation of $\mathrm{SiO}$ vapor in the powder mixture with a same composition as a sialon with $z=2$ was not good enough for reaction sintering, because the equilibrium $\mathrm{SiO}$ pressure is to be $3.9 \times 10^{-1} \mathrm{~atm}$ at $1800^{\circ} \mathrm{C}$ due to the formation of $15 \mathrm{R}$-sialon by the thermal decomposition of $\beta$-sialon formed.

The successful sintering by packing the compact with the powder mixture of $\mathrm{Si}_{3} \mathrm{~N}_{4}$ and $\mathrm{SiO}_{2}$ is associated with the formation of $\mathrm{Si}_{2} \mathrm{~N}_{2} \mathrm{O}$ at the surface of and around the compact, and it was confirmed by $\mathrm{X}$-ray diffraction studies. That is,

$$
\mathrm{Si}_{3} \mathrm{~N}_{4}(\mathrm{~s})+\mathrm{SiO}_{2}(\mathrm{~s})=2 \mathrm{Si}_{2} \mathrm{~N}_{2} \mathrm{O}(\mathrm{s})
$$

The thermal decomposition of $\mathrm{Si}_{2} \mathrm{~N}_{2} \mathrm{O}$ produces $\mathrm{SiO}$ by a reaction,

$$
3 \mathrm{Si}_{2} \mathrm{~N}_{2} \mathrm{O}(\mathrm{s})=\mathrm{Si}_{3} \mathrm{~N}_{4}(\mathrm{~s})+3 \mathrm{SiO}(\mathrm{g})+\mathrm{N}_{2}(\mathrm{~g})
$$

The equilibrium partial pressure of $\mathrm{SiO}$ on $\mathrm{Si}_{2} \mathrm{~N}_{2} \mathrm{O}$ under total pressure of $1 \mathrm{~atm}$ was calculated as $4.8 \times 10^{-1} \mathrm{~atm}$ at $1800^{\circ} \mathrm{C}$. The value is in the stable region of $\beta$-sialon as shown in Fig. 2. Under sufficient $\mathrm{SiO}$ pressure on the compact, the weight loss due to the thermal decomposition of $\beta$-sialon during heating at $1800^{\circ} \mathrm{C}$ was very small as shown in Table 2 , so that the compact was sintered without the shift in composition. The present method does not necessitate the shift to the oxide-rich composition with respect to $\beta$-sialon by oxidizing the starting powder ${ }^{16}$.

The fabrication of high density $\beta$-sialon by heating the compact packed in $\mathrm{Si}_{3} \mathrm{~N}_{4}$ or same composition might be associated with small shift in composition of the compact to oxide corner in $\mathrm{Si}_{3} \mathrm{~N}_{4}-\mathrm{SiO}_{2}-\mathrm{Al}_{2} \mathrm{O}_{3}-\mathrm{AlN}$ phase diagram. The addition of more than $4 \mathrm{wt} \%$ of alumina to $\beta$-sialon composition made possible to be sintered to high density without supplying sufficient $\mathrm{SiO}$ pressure.

The present method to heat the compact in $\mathrm{Si}_{3} \mathrm{~N}_{4}$ and $\mathrm{SiO}_{2}$ mixture enabled the sintering of $\beta$-sialon with improved mechanical properties $^{15)}$.

\section{Summary}

(1) The thermal decomposition reaction of two-phase sialon containing both $\beta$-sialon with $z=2.3$ and X-phase and single-phase $\beta$ sialon with $z=2$ was studied by heating the specimen at $1800^{\circ} \mathrm{C}$ under 1 atm $\mathrm{N}_{2}$.

(2) Two-phase sialon decomposed thermally to $\beta$-sialon, $\mathrm{SiO}$ and $\mathrm{N}_{2}$. Single-phase sialon decomposed to $15 \mathrm{R}$-sialon, $\mathrm{SiO}$ and $\mathrm{N}_{2}$.

(3) The region of $\mathrm{SiO}$ pressure for the stable single-phase $\beta$-sialon with $z=2$ was calculated to be in the range from $6.0 \times 10^{-1}$ to $3.9 \times 10^{-1} \mathrm{~atm}$ at $1800^{\circ} \mathrm{C}$.

(4) The reaction sintering of $\beta$-sialon from powder mixture of $\mathrm{Si}_{3} \mathrm{~N}_{4}, \mathrm{Al}_{2} \mathrm{O}_{3}$ and $\mathrm{AlN}$ was successfully performed when the compact was packed with powder mixture of $\mathrm{Si}_{3} \mathrm{~N}_{4}$ and $\mathrm{SiO}_{2}$. The prevention of thermal decomposition of $\beta$-sialon during sintering is attributed to the formation of $\mathrm{Si}_{2} \mathrm{~N}_{2} \mathrm{O}$ and resulting $\mathrm{SiO}$ pressure of $4.8 \times 10^{-1} \mathrm{~atm}$ at $1800^{\circ} \mathrm{C}$. The presence of sufficient vapor pressure of $\mathrm{SiO}$ on the compact enabled the fabrication of high density $\beta$-sialon with small amount of intergranular phase.

\section{References}

1) K.H. Jack, J. Mater. Sci., 11, 1136 (1976).

2) L.J. Gauckler, S. Prietzel, G. Bodemer and G. Petzow, Proc. NATO Adv. Study Inst., "Nitrogen Ceramics", Ed. F.L. Riley, Noordhoff Int. Pub., (1977) p. 529.

3) M. Mitomo, N. Kuramoto and H. Suzuki, Proc. Int. Symp. of Factors in Densification and Sintering of Oxide and Non-oxide Ceramics, (1978) p. 463.

4) R.R. Wills, R.W. Stewart and J.M. Wimmer, J. 
Am. Ceram. Soc., 60, 64 (1977).

5) S. Boskovic, L.J. Gauckler, G. Petzow and T.Y. Tien, Powder Metal. Inter., 9, 185 (1977).

6) J. Briggs, Mater. Res. Bull., 12, 1047 (1977).

7) P. Goursat, Proc. NATO Adv. Study Inst., "Nitrogen Ceramics", Ed. F.L. Riley, Noordhoff Inter. Pub. (1977) p. 81.

8) L.J. Gauckler, H.L. Lukas and G. Petzow, J. Am. Ceram. Soc., 58, 346 (1975).

9) M. Mitomo, Y. Yajima and N. Kuramoto, ibid., 62, 316 (1979).

10) M. Mitomo, J. Mater. Sci., 11, 1103 (1976).

11) G.E. Gazza and R.N. Katz, Proc. D.O.E. Highway Vehicle Systems Contractor's Co-ordination Meeting, Oct. 1978.
12) K.H. Jack, Final Technical Report, DAERO-76G-067, 1977.

13) JANAF Thermochemical Tables, (U.S. Air Force Contact, AF 04 (611)-7554, Aug. 1975).

14) R.A. Robie and D.R. Waldbaum, "Thermodynamic Properties of Minerals and Related Substances at $198.15^{\circ} \mathrm{K}$ and One Atmosphere Pressure and at High Temperature" (U.S. Geol. Sur. Bull., 1259, 1968).

15) M. Mitomo, N. Kuramoto and Y. Inomata, $J$. Mater. Sci., 14, 2309 (1979).

16) L.J. Gauckler, S. Boskovic, I.K. Naik and T.Y. Tien, Proc. of the Workshop on Ceramics for Advanced Heat Engines, Florida (1977) p. 321.

実験・技術・調查報告・Report

\title{
下水污泥焼却灰からの人工軽量骨材の製造
}

\author{
大 森 志郎・荒 井怜 \\ （工業技術院 公害資源研究所）
}

下水污泥燒却灰に膨張性ケツ岩を添加して, 人工軽量骨材原料としての可能性を検討した.

下水污泥焼却灰は単味では発泡膨張しないが, 焼却灰に膨張性ケツ岩を $20 \%$ 以上添加して, 造 粒し, 燒成温度 $1140^{\circ}, 1150^{\circ} \mathrm{C}$ の 2 水準で実験した結果, 添加物の増加とともに絶乾比重が小さく なり, 造粒も容易になる. しかし, 添加物の量が $20 \%$ 以下の場合は造粒物の十分な強度が得られ ない.

そこで, バッチ型ロータリーキルンで膨張性ケツ岩を $20 \%$ 添加し, 造粒, 乾燥後, 焼成温度 $1160^{\circ}$ C, 焼成保持時間 30 分で燒成した結果，絶乾比重 1.05 , 吸水率 $4.1 \%$ で，この粗骨材を使用した コンクリートの圧縮強度は, 水/セメント比 (W/C) $40 \%$ で, 材令 28 日の場合に $352 \mathrm{~kg} / \mathrm{cm}^{2}$ で, 市販品を使用した場合と同程度の強度があり，人工軽量骨材原料としての可能性を得た.

(1978 年 12 月 12 日受付)

\section{Production of Lightweight Aggregate from Cindered Sludge of Urban Sewage}

\author{
Shiro OMORI and Satoshi ARAI
}

(National Research Institute for Pollution and Resources, Kawaguchi-shi 332)

Expanded aggregates were experimentally produced from cindered sludge of urban sewage.

The cindered sludge itself was not a suitable material for this purpose, but with the aid of over $20 \%$ expanded shale it was proved to be possible. When the amount of shale was less than $20 \%$, the pelletizing was very difficult and the expansion property was worse. The experimental results suggested that the pellets had to be fired at $1160^{\circ} \mathrm{C}$ for $30 \mathrm{~min}$.

The specifications of lightweight aggregate produced by a test rotary kiln were as follows: (1) the specific gravity was 1.05 , (2) the $24 \mathrm{~h}$ water absorption was $4.1 \%$, (3) the 28 day compressive strength of the concrete was $352 \mathrm{~kg} / \mathrm{cm}^{2}$.

According to those results, the aggregate produced was acceptable for use in structural concrete.

[Received December 12, 1978] 